\title{
Efektifitas career decision-making course dalam upaya menanggulangi kesulitan siswa untuk mengambil keputusan karier
}

\author{
Whisnu Yudiana ${ }^{(1)}$, Annisa Laksmi Dewanti ${ }^{(2)}$, Ocha Ananda Suherik $^{(3)}$, Surya Cahyadi ${ }^{(4)}$ \\ ${ }^{(1)}$ Departemen Psikologi Umum dan Eksperimen, Universitas Padjadjaran, Bandung, \\ Indonesia \\ (2), (4) Departemen Psikologi Pendidikan, Universitas Padjadjaran, Bandung, Indonesia \\ ${ }^{(3)}$ Prodi Sarjana Psikologi, Universitas Padjadjaran, Bandung, Indonesia
}

Entering the transition period from early adolescence to late adolescence, senior high school students oftentimes experience uncertainty in determining what they should do after completing their education. This research aimed to examine the effectiveness of the Career Decision-Making Course $(C D M C)$ as an intervention to deal with senior high school students' career decision-making difficulties. The three main categories of career decision-making difficulties investigated in this research included lack of readiness, lack of information, and inconsistency of information. Participants were 35 private high school students in the city of Bandung. The effectiveness of CDMC was tested through a pretest-posttest only design experiment. The results revealed that CDMC was effective in helping students deal with career decision-making difficulties, especially those related to lack of readiness and lack of information. However, CDMC did not significantly reduce the difficulty originating from the problem of inconsistency of information. The findings in this research imply that senior high school students should be provided with adequate information about various alternative careers that they can choose so that they are ready to determine the next step after finishing their education.

Keywords: Career Decision-Making Course (CDMC), career difficulties, senior high school students

Memasuki masa transisi dari remaja awal ke remaja akhir, siswa sekolah menengah atas seringkali mengalami kebimbangan dalam menentukan apa yang harus mereka lakukan setelah menyelesaikan pendidikan. Penelitian ini bertujuan untuk mengujikan efektivitas dari Career Decision-Making Course (CDMC) sebagai sebuah interventi untuk menangani kesulitan penentuan karier tersebut. Tiga kategori utama dalam kesulitan karier yang diteliti adalah kurangnya kesiapan, kurangnya informasi, dan inkonsistensi informasi. Partisipan adalah 35 siswa menengah atas swasta di kota Bandung. Efektivitas CDMC diuji melalui eksperimentasi pretest-posttest only design. Hasil menunjukkan bahwa CDMC efektif menangani kesulitan siswa untuk mengambil keputusan karier, terutama yang berkaitan dengan kesulitan pengambilan keputusan karena kurangnya kesiapan dan kurangnya informasi. Sementara itu, CDMC tidak berpengaruh signifikan dalam menurunkan kesulitan karena permasalahan inkonsistensi informasi. Hasil penelitian ini memberikan implikasi bahwa siswa sekolah menengah atas perlu dibekali informasi yang memadai mengenai berbagai macam alternatif karier yang bisa mereka pilih agar mereka siap menentukan langkah ke depan setelah menyelesaikan pendidikan.

Kata kunci: Career Decision-Making Course (CDMC), kesulitan karier, siswa sekolah menengah atas

MEDIAPSI, 2021, Vol. 7(2), 95-106, DOI: https://doi.org/10.21776/ub.mps.2021.007.02.2

Received: 08-02-2019. Revised: 14-07-2021. Accepted: 29-07-2021. Published online: 25-12-2021

Handling Editor: Ali Mashuri, Universitas Brawijaya, Malang, Indonesia.

*Corresponding author: Whisnu Yudiana, Departemen Psikologi Umum dan Eksperimen, Universitas Padjadjaran,

Bandung Indonesia. E-mail: whisnu.yudiana@unpad.ac.id

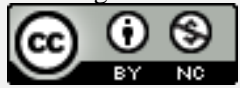

This work is licensed under a Creative Commons Attribution-NonCommercial 4.0 International License.

How to cite this article in accordance with the American Psychological Association (APA) $7^{\text {th }}$ guidelines:

Yudiana, W., Dewanti, A. L., Suherik, O. A., \& Cahyadi, S. (2021). Efektifitas career decision-making course dalam upaya menanggulangi kesulitan siswa untuk mengambil keputusan karier. MEDIAPSI, 7(2), 95-106. https://doi.org/10.21776/ub.mps.2021.007.02.2 


\section{Pendahuluan}

Setelah lulus dari sekolah menengah atas, individu menghadapi dua pilihan karier yang sangat menentukan yaitu melanjutkan studi ke perguruan tinggi atau memulai meniti karier sebagai pekerja (Nurihsan \& Sudianto, 2005). Pengambilan keputusan karier ini tidaklah mudah. Hal ini dibuktikan oleh beberapa temuan penelitian yang menyatakan bahwa sebagian besar siswa mengalami kesulitan dalam pengambilan keputusan karier (Creed dkk., 2006; Dewanti, 2018; Fadhillah \& Yudiana, 2020). Mereka kurang memiliki informasi mengenai karier yang akan di ambilnya (Hidayati, 2015; Novitasari, 2013) dan siswa belum dapat mengambil keputusan karier karena mereka belum yakin dengan keputusan yang akan di ambilnya ataupun perencanaan karier ke depan (Komara, 2016; Pramudi, 2015). Alasan-alasan mengenai kesulitan dalam keputusan karier tersebut dijelaskan secara komprehensif dalam taxonomy of career decision-making difficulties. Mengacu pada taksonomi ini, kesulitan dalam keputusan karier bersumber dari kesulitan dalam membuat keputusan karier dengan segera (lack of readiness), kurangnya akses dan penggunaan informasi (lack of information), dan adanya informasi yang tidak konsisten atau tidak kongruen antara dua jenis informasi yang diperoleh (inconsistent information) (Gati dkk., 1996).

Beberapa intervensi telah dilakukan untuk membantu siswa dalam menanggulangi kesulitan pengambilan keputusan di permasalahan karier seperti memberikan layanan informasi karier dengan berbagai media informasi (Aminuddin \& Mulyadi, 2020; Risqiyain
\& Purwanta, 2019) dan pembuatan modul bimbingan karier (Atmaja, 2014). Hanya saja, intervensi-intervensi tersebut masih sebatas pada masalah kesulitan lack of information, sementara untuk lack of readiness dan inconsistent information belum tertangani. Selanjutnya, siswa yang mengalami keraguan dapat membuat sulit melakukan pilihan karier dan akademik yang dapat berdampak pada karier masa depan mereka dan kesuksesan dalam pekerjaan (Fouad dkk., 2009; Gati dkk., 1996).

Dewanti (2018) membuat rancangan modul career decision-making course (CDMC) yang bertujuan untuk mengatasi kesulitan dalam membuat keputusan karier. Career course adalah metode untuk menyampaikan pelayanan karier yang komprehensif kepada individu (Fouad dkk., 2009). Fokus dalam career course adalah memberikan pemahaman mengenai faktor dalam memilih karier, informasi karier, teknik mencari pekerjaan, dan career decision-making. Rancangan modul ini tidak hanya menyasar kurangnya informasi akan tetapi mencoba untuk menangani lack of readiness dan inconsistent information pada diri individu. Selain itu, berdasarkan expert panel rancangan modul ini dapat membantu dalam menangani kesulitan individu dalam pengambilan keputusan (Dewanti, 2018). Hanya saja hingga sekarang belum ada bukti empiris yang menyatakan bahwa modul ini dapat membantu mengurangi kesulitan siswa dalam pengambilan keputusan karier. Dengan demikian, keefektifan pelatihan CDMC tersebut perlu dievaluasi.

Penelitian ini dilakukan dengan tujuan untuk mengevaluasi dua level dari pelatihan yaitu evaluasi reaksi dan evaluasi 
proses belajar berdasarkan kerangka evaluasi (Kirkpatrick, 1998). Penelitian mengenai hal ini penting karena hanya beberapa penelitian yang secara sistematis mengevaluasi dampak dan hasil dari intervensi karier yang dirancang untuk mengurangi kesulitan pengambilan keputusan (Lam \& Santos, 2018). Selain itu, hasil dari penelitian ini dapat digunakan oleh psikolog dan praktisi di bidang pendidikan untuk melakukan intervensi penanganan kesulitan pengambilan keputusan pada siswa. Secara lebih spesifik, penelitian ini bertujuan untuk melihat efektivitas dari pemberian career decision-making course terhadap pengurangan kesulitan pengambilan keputusan karier pada siswa sekolah menengah atas.

\section{Metode \\ Partisipan dan desain penelitian}

Partisipan penelitian ini adalah 35 siswa Kelas XII di salah satu Sekolah Menengah Atas (SMA) swasta di Bandung. Penelitian ini bersifat sukarela, dimana siswa diberikan inform consent untuk menyatakan kesediaan untuk mengikuti CDMC. Sebagian besar partisipan berjenis kelamin perempuan yaitu 23 siswa (65\%) sementara sisanya adalah laki-laki sebanyak 12 siswa (35\%). Usia peserta berkisar antara 16 - 18 tahun, dengan rata-rata usia $17.00(S D=0.48)$ tahun. Dilihat dari suku bangsa, sebagian besar responden berasal dari suku Sunda berjumlah 20 siswa (57.11\%), diikuti oleh suku Jawa berjumlah 9 siswa (25.7\%), dan sisanya adalah Batak dan Minang yang masing-masing berjumlah 3 siswa (8.6\%). Desain penelitian adalah eksperimen pretest-posttest (Christensen, 2010).

\section{Prosedur dan pengukuran}

Pada tahap awal penelitian (pre-test), peneliti melakukan pengambilan data awal kepada peserta yang berkaitan dengan gambaran kesulitan dalam membuat keputusan karier partisipan. Kemudian peneliti memberikan pelatihan career decision-making course (CDMC) kepada peserta. Setelah diberikan pelatihan, maka gambaran kesulitan partisipan dalam membuat keputusan karier sebagai data post-test diukur kembali.

Terdapat dua instrumen yang digunakan dalam penelitian ini. Instrumen utama bertujuan untuk melihat tingkat kesulitan siswa dalam mengambil keputusan karier, yang diukur dengan menggunakan Career Decision Making Difficulties Questionnaire (CDDQ; Gati dkk., 1996). Instrumen tersebut telah melalui proses adaptasi dan norma untuk populasi Indonesia, yang terdiri dari 34 butir soal dengan nilai reliabilitas .94 (Jayanti, 2018). Pada instrumen ini responden diminta untuk menjawab dengan menggunakan skala 1 (sangat tidak sesuai) sampai dengan 9 (sangat sesuai). Skor total di rata-ratakan sehingga rentang skor tetap berada pada 1 sampai dengan 9 , dimana semakin besar skor individu semakin mengalami kesulitan dalam pengambilan keputusan.

Lebih lanjut, Jayanti (2018) menjelaskan bahwa skor dalam CDDQ dibagi menjadi tiga kategori berdasarkan skor yang didapatkan. Pertama adalah skor $>$ 6.34, yang termasuk dalam kategori "salient" yang mencerminkan individu yang mengalami kesulitan berat dan memerlukan bantuan konselor atau pihak ahli lainnya dalam menangani kesulitan tersebut. Kedua adalah skor antara 3.33 sampai dengan 6.33, yang termasuk dalam 
kategori "moderate”. Kategori kedua ini mencerminkan kesulitan yang dirasakan minim, dan individu cukup memadai untuk mampu membuat keputusan karier. Ketiga adalah skor $<3.33$, yang termasuk kategori "negligible yaitu kesulitan yang dirasakan minim, dan individu sudah cukup memadai untuk mampu membuat keputusan karier. Kategorisasi tersebut sesuai dengan prosedur yang telah ditetapkan sebelumnya (Gati dkk., 1996; Gati \& Levin, 2014). Selain menghasilkan keseluruhan aspek dalam kesulitan dalam pengambilan keputusan, instrumen CDDQ menggambarkan kategori umum kesulitan yang dirasakan sulit oleh individu, yaitu readiness, lack of information, dan inconsistent information. Kategori umum tersebut memberikan informasi yang lebih detail mengenai aspek dalam kesulitan pengambilan keputusan dalam karier individu.

Instrumen kedua yang digunakan dalam penelitian ini berkaitan dengan evaluasi reaksi peserta pada pelatihan. Aspek yang dievaluasi dalam pelatihan ini berkaitan dengan metode dan materi, pemateri, waktu kegiatan dan kebermanfaatan. Instrumen ini terdiri dari 10 butir soal dengan pilihan jawaban dari 1 (kurang baik) sampai dengan 5 (sangat baik) dengan nilai reliabilitas sebesar .70 .

Penyusunan modul pelatihan diadaptasi berdasarkan modul "Career Decision Making Course (CDMC)" yang telah dikembangkan sebelumnya (Dewanti, 2018). CDMC merupakan aktivitas pembelajaran sekuensial yang dirancang untuk membantu partisipan memiliki kompetensi dalam membuat keputusan karier. Penyesuaian dilakukan berkaitan dengan konten. Hal ini dilakukan karena pada penelitian sebelumnya konten berkaitan dengan pengembangan karier pada mahasiswa. Sementara itu, pada penelitian ini partisipan adalah siswa menengah atas. Modul CDMC ini dikembangkan berdasarkan pada lima career choice competencies (Crites, 1978), yang mencakup (1) kemampuan individu untuk secara akurat menilai kemampuan, minat, dan value yang dimiliki terkait keputusan karier (accurate self-appraisal), (2) kemampuan untuk menemukan berbagai sumber informasi mengenai pilihan pendidikan atau pekerjaan (gathering occupational information), (3) kemampuan untuk mencocokkan karakteristik diri dengan pilihan karier dalam rangka menentukan karier yang akan dicapai (goal selection), (4) kemampuan mengetahui bagaimana mengimplementasikan pilihan karier (making plans for the future), dan (5) kemampuan menemukan alternatif rencana atau strategi penyelesaian ketika rencana tidak berjalan seperti yang diharapkan (problem-solving). Berdasarkan hal tersebut maka modul ini terbagi menjadi empat sesi yang berdurasi dua hari. Dalam setiap sesi, partisipan dibagi ke dalam kelompok yang berjumlah 6 sampai 7 orang dengan dipandu oleh dua orang fasilitator yang sebelumnya telah diberikan pelatihan pengembangan karier.

Keseluruhan proses pelatihan menggunakan pendekatan experiential learning (Kolb, 1976, 2014). Melalui pendekatan experiential learning, tahapan pembelajaran dimulai dengan partisipan mempertimbangkan konsep, masalah atau situasi, kemudian memeriksa solusi alternatif dan mengevaluasi konsekuensi dari sebuah solusi yang diutarakan (Kolb, 1976). Pemilihan pendekatan ini dikarena experiential learning mengembangkan 
pembelajaran secara aktif melalui pengalaman dan refleksi terhadap pengalaman tersebut (Cornell dkk., 2013).

\section{Hasil}

Analisa statistik deskriptif digunakan untuk melakukan evaluasi reaksi dan gambaran awal dari peserta menyangkut kategori kesulitan siswa dalam mengambil keputusan karier, berupa rata-rata total dan setiap aspek kesulitan siswa. Sementara itu, pengujian inferensial menggunakan $t$ test untuk data berpasangan yang digunakan untuk melakukan evaluasi proses belajar. Analisa effect size cohen'd dihitung untuk mengetahui besarnya pengaruh pelatihan (Cohen, 1988). Nilai $d$ $=0.2$ berarti efek rendah, $d=0.5$ berarti efek sedang, $d=0.8$ berarti efek besar (Cohen, 1988). Semua proses analisa dilakukan dengan menggunakan Statistical Package for the Social Sciences (SPSS) versi 20 untuk Macintosh.

Partisipan melakukan evaluasi reaksi terhadap empat aspek yaitu metode dan materi, pemateri, waktu kegiatan dan kebermanfaatan. Pada Tabel 1 dapat dilihat bahwa hampir secara keseluruhan rata-rata penilaian peserta terhadap pelatihan yang diberikan adalah 3.26 ( $S D$ $=0.55)$ dengan rentang penilaian 1 (kurang baik) sampai dengan 5 (sangat baik) dan nilai tengah adalah 3. Dari hasil ini, dapat disimpulkan bahwa penilaian peserta terhadap pelatihan CDMC adalah cukup baik. Penilaian tertinggi adalah kebermanfaatan materi $(M=3.61, S D=$ 0.54) diikuti oleh penguasaan materi dari pemberi materi $(M=3.56, S D=0.50)$ dan kebermanfaat dalam membantu dalam persiapan untuk mencapai $\operatorname{karier}(M=$ 3.46, $S D=0.55)$. Namun pada aspek waktu $(M=2.59, S D=0.77)$ dan mengidentifikasi kelebihan dan kekurangan individu masih perlu ditingkatkan $(M=3.17, S D=0.50)$.

Kesulitan pengambilan keputusan karier dibagi menjadi tiga kelompok yaitu negligible, moderate, dan salient. Pada Tabel 2 tersaji proporsi partisipan yang masuk ke dalam kategori salient dan negligible pada sebelum pelatihan masingmasing adalah sebanyak 6 (17.14\%). Salient adalah siswa yang mengalami hambatan yang besar dalam pengambilan keputusan terhadap karier. Setelah pelatihan dapat dilihat bahwa jumlah partisipan yang masuk kedalam kategori salient berkurang sebanyak lima orang dan tersisa 1 orang. Sementara pada partisipan yang masuk ke dalam kategori negligible atau tidak mengalami hambatan, mengalami peningkatan sebanyak $50 \%$ menjadi $12(34.29 \%)$.

Tabel 1. Evaluasi Reaksi Pelatihan CDMC.

\begin{tabular}{lcc}
\hline Aspek Penilaian & $M$ & $S D$ \\
\hline Metode Dan Materi & 3.22 & 0.61 \\
Dukungan lembar kerja & 3.17 & 0.44 \\
Ketepatan metode & & \\
Pemateri & 3.56 & 0.50 \\
Penguasaan materi & 3.29 & 0.46 \\
Penyampaian materi menarik & & \\
\hline
\end{tabular}


Tabel 1. (Lanjutan).

\begin{tabular}{lcc}
\hline Aspek Penilaian & $M$ & $S D$ \\
\hline Waktu & 3.05 & 0.63 \\
$\begin{array}{l}\text { Durasi waktu } \\
\text { Waktu pelaksanaan }\end{array}$ & 2.59 & 0.77 \\
Kebermanfaatan & 3.61 & 0.54 \\
Materi yang diberikan bermanfaat & 3.46 & 0.55 \\
$\begin{array}{l}\text { Membantu dalam persiapan untuk } \\
\text { mencapai karier }\end{array}$ & 3.46 & 0.55 \\
$\begin{array}{l}\text { Menambah pengetahuan tentang karier } \\
\text { Membantu mengidentifikasi kelebihan dan }\end{array}$ & 3.17 & 0.50 \\
kekurangan & 3.26 & 0.55 \\
Total & & \\
\hline
\end{tabular}

Keterangan. $M=$ rata-rata. $S D=$ deviasi standar.

Dalam upaya melihat efek dari proses belajar maka digunakan instrumen Career Decision Making Difficulties Questionnaire (CDDQ). Pada Tabel 3 dilaporkan bahwa seluruh skor dari hasil pre-test lebih tinggi dibandingkan skor dari post-test. Namun demikian, tidak seluruh skor menurun secara signifikan. Pada level nilai total dan aspek CDDQ, skor total CDDQ pada saat pre-test $(M=$ $4.72, S D=1.55)$ dibandingkan pada saat post-test $(M=4.02, S D=1.39)$ dan perbedaannya adalah signifikan $(t[34]=$
3.25, $p<0.01, d=-0.32]$, dengan perbedaan yang terjadi termasuk ke dalam taraf rendah. Artinya, pelatihan secara signifikan menurunkan kesulitan dalam pengambilan keputusan dalam karier. Pelatihan juga secara signifikan menurunkan aspek readiness $(t[34]=3.47$, $p<0.01 . d=-0.47)$ pada taraf rendah ke sedang dan aspek information $(t[34]=$ $3.54, p<0.01, d=-0.27)$ pada taraf rendah. Sementara pada aspek inconsistent perubahan yang terjadi tidaklah signifikan $(t[34]=1.13, p<0.37, d=-0.11)$.

Tabel 2. Perubahan Kategori Kesulitan Pengambilan Keputusan.

\begin{tabular}{lcccc}
\hline \multirow{2}{*}{ Kategori } & \multicolumn{2}{c}{ Pretest } & \multicolumn{2}{c}{ Posttest } \\
\cline { 2 - 5 } & $n$ & $\%$ & $n$ & $\%$ \\
\hline Negligible & 6 & $17.14 \%$ & 12 & $34.29 \%$ \\
Moderate & 23 & $65.71 \%$ & 22 & $62.86 \%$ \\
Salient & 6 & $17.14 \%$ & 1 & $2.86 \%$ \\
\hline
\end{tabular}

Keterangan. $n=$ jumlah partisipan pada pretest dan posttest. 
Jika ditinjau lebih detail berdasarkan subaspek maka pada aspek readiness pelatihan secara signifikan menurunkan nilai lack of motivation, $(t[34]=2.17, p<$ $0.05, d=-0.24)$ dan dysfunctional belief $(t[34]=2.98, p<0.05, d=-0.28)$, yang penurun keduanya termasuk dalam kategori rendah. Hal yang serupa terjadi pada subaspek information. Keseluruhan aspek information mengalami penurunan pada level yang rendah (rentang $d=-0.18$

\section{Diskusi}

Pada bagian ini akan dibahas mengenai evaluasi dari hasil reaksi dan evaluasi proses belajar yang Career Decision Making Course (CDMC)". Berdasarkan evaluasi dari reaksi, secara umum modul ini dinilai positif oleh peserta. Secara spesifik pada aspek metode dan materi dukungan, lembar kerja peserta yang digunakan untuk mengidentifikasi kemampuan, minat, dan nilai dirasakan cukup baik. Hal ini sesuai dengan penelitian lain yang menyatakan bahwa bantuan media sangat membantu individu dalam mengidentifikasi karakteristik individu (Atmaja, 2014).

Pemateri dinilai menguasai materi yang diberikan dan metode yang diberikan pun masih dinilai positif oleh peserta. Hal ini berkaitan dengan pemberian metode experiential learning. Melalui pengembangan pembelajaran secara aktif maka siswa dapat melakukan refleksi terhadap pengalaman yang telah didapatkan (Cornell dkk., 2013). Dengan demikian peserta dapat lebih memahami proses yang diberikan dalam pelatihan tersebut. Hal ini terlihat dari aspek kebermanfaatan pelatihan CDMC yang dirasakan paling tinggi. Berdasarkan sampai dengan -0.32). Subaspek Ways of Obtaining Career Information memiliki nilai perubahan yang paling tinggi dibandingkan dengan tiga aspek yang lain, $t(34)=3.29, p<0.01, d=-0.32$, dan yang terendah pada ocupations, $t(34)=2.53, p<$ $0.05, d=-0.18$. Sementara itu. pada tiga subaspek Unreliable Information, Internal Conflict, dan External Conflict, penurunan yang terjadi dari proses pelatihan tidak signifikan (lihat Tabel 3).

penilaian reaksi, peserta merasakan bahwa pelatihan ini dapat membantu mereka dalam mempersiapkan untuk mencapai karier yang diinginkan.

Aspek waktu dinilai paling rendah dibandingkan dengan aspek yang lain terutama waktu pelaksanaan. Hal ini dikarenakan waktu pelaksanaan berada pada akhir semester satu dimana mereka menilai bahwa waktu tersebut terlalu berdekatan dengan persiapan yang harus mereka lakukan dalam ujian masuk perguruan tinggi. Sementara itu, berdasarkan evaluasi terhadap proses belajar, CDMC menurunkan kesulitan siswa untuk mengambil keputusan terhadap karier. Jumlah peserta yang mengalami kesulitan dengan kategori salient berkurang secara signifikan. Proses yang dilakukan dalam pelatihan ini adalah menanamkan pengetahuan kepada siswa untuk mengenal diri (know yourself), mampu untuk mengidentifikasi pilihan pilihan karier (identifying options), mengevaluasi pilihan (evaluate options), dan membuat rencana karier (make a plan). 
Tabel 3. Evaluasi Proses Belajar Pelatihan CDMC.

\begin{tabular}{|c|c|c|c|c|c|c|c|}
\hline \multirow{2}{*}{ Aspek } & \multirow{2}{*}{$n$} & \multicolumn{2}{|c|}{ Pre-test } & \multicolumn{2}{|c|}{ Post-test } & \multirow{2}{*}{$t$} & \multirow{2}{*}{$\begin{array}{l}\text { Effect } \\
\text { Size }\end{array}$} \\
\hline & & $M$ & $S D$ & $M$ & $S D$ & & \\
\hline CDDQ Total & 35 & 4.72 & 1.55 & 4.02 & 1.39 & $3.25 * *$ & -0.32 \\
\hline Readiness & 35 & 4.96 & 1.17 & 4.33 & 1.14 & $3.47 * *$ & -0.47 \\
\hline Lack of Motivation & 35 & 3.48 & 1.71 & 2.82 & 1.58 & $2.17 *$ & -0.24 \\
\hline General Indecisiveness & 35 & 5.81 & 1.94 & 5.26 & 1.81 & $1.95 *$ & -0.16 \\
\hline Dysfunctional Beliefs & 35 & 5.60 & 1.60 & 4.92 & 1.54 & $2.98 *$ & -0.28 \\
\hline Information & 35 & 4.87 & 2.19 & 3.82 & 1.74 & $3.54 * *$ & -0.27 \\
\hline $\begin{array}{l}\text { Career Decision Making } \\
\text { Process }\end{array}$ & 35 & 5.20 & 2.51 & 4.06 & 2.05 & $3.24 * *$ & -0.22 \\
\hline Self & 35 & 4.61 & 2.48 & 3.54 & 1.92 & $2.96^{*}$ & -0.22 \\
\hline Occupations & 35 & 4.91 & 2.30 & 4.08 & 1.94 & $2.53 *$ & -0.18 \\
\hline $\begin{array}{l}\text { Ways of Obtaining Career } \\
\text { Information }\end{array}$ & 35 & 4.74 & 2.12 & 3.59 & 1.64 & $3.29 * *$ & -0.32 \\
\hline Inconsistent & 35 & 4.28 & 1.71 & 3.99 & 1.61 & 1.13 & -0.11 \\
\hline Unreliable Information & 35 & 4.16 & 1.81 & 4.11 & 1.78 & 0.15 & -0.02 \\
\hline Internal Conflict & 35 & 4.33 & 1.78 & 3.98 & 1.64 & 1.29 & -0.12 \\
\hline External Conflict & 35 & 4.36 & 2.72 & 3.89 & 2.15 & 0.95 & -0.08 \\
\hline
\end{tabular}

Keterangan. $n=$ jumlah partisipan. $M=$ rata-rata. $S D=$ deviasi standar. ${ }^{*}{ }^{*} p<0.01 .{ }^{*} p<0.05$.

Sesi pertama yaitu "know yourself" merupakan upaya untuk secara akurat siswa dapat mengenal dirinya yang merupakan kompetensi penting dalam karier (Crites, 1978). Pada sesi ini, peserta menggunakan alat bantu berupa buku kerja peserta yang berisi kuesioner diri yang mencakup minat, nilai, dan kemampuan, serta buku panduan menyangkut jurusan- jurusan di perguruan tinggi. Sesi kedua adalah "Identifying Options" atau mengidentifikasi pilihan-pilihan karier. Aktivitas yang dilakukan berkaitan dengan pengembangan kemampuan untuk menemukan berbagai sumber informasi mengenai pilihan pendidikan atau pekerjaan. Beberapa sumber informasi yang dapat digunakan adalah internet, 
buku panduan jurusan di perguruan tinggi, dan narasumber lulusan serta mahasiswa dari perguruan. Selain itu, untuk dapat menggali informasi yang tepat partisipan diberikan informasi mengenai bagaimana melakukan wawancara yang tepat.

Tujuan utama dari sesi pertama dan kedua dalam CDMC adalah untuk mendorong siswa untuk lebih mengenal diri dan pilihan karier dan lebih mengetahui cara untuk mendapatkan kedua informasi tersebut. Siswa yang mengalami permasalahan karier sering tidak dapat dengan mudah membuat keputusan karena terbatasnya informasi yang dimiliki untuk membuat pilihan, atau karena tidak mengenali dirinya sendiri (Nathan \& Hill, 2005). Dengan melihat hasil penelitian, kategori kesulitan utama kedua yaitu lack of information siswa mengalami penurunan secara signifikan. Artinya, CDMC secara efektif dapat membantu mengurangi kesulitan siswa yang berkaitan dengan kurangnya informasi mengenai bagaimana proses pembuatan keputusan karier, kurangnya informasi mengenai diri, kurangnya informasi mengenai pekerjaan atau jurusan untuk siswa dan kurangnya mengenai bagaimana cara memperoleh suatu informasi, selaras dengan taxonomy of career decision-making difficulties (Gati dkk., 1996).

Dalam permasalahan keputusan karier, siswa harus diajarkan kemampuan dasar pengambilan keputusan yang dapat membantunya dalam proses pengambilan keputusan dan membantunya dalam mendapatkan peluang karier yang lebih baik (Gati \& Saka, 2001). Dengan demikian, sesi ke tiga adalah "evaluate options" yaitu pengembangan kemampuan untuk bagaimana membuat keputusan dalam karier. Siswa diminta untuk mengevaluasi informasi-informasi yang telah diperoleh pada sesi sebelumnya baik pilihan karier ataupun informasi diri dengan cara memberikan penilaian hal-hal apa saja yang penting untuk dilakukan terhadap pilihan karier tersebut dan hal tidak penting yang tidak boleh dilakukan yang dapat menghambat pilihan karier. Sesi ini dilanjutkan dengan sesi terakhir yaitu "make a plan" yaitu tahap dimana peserta mengetahui bagaimana cara mengimplementasikan pilihan karier dan mengetahui cara menemukan alternatif rencana atau strategi penyelesaian ketika rencana tidak berjalan seperti yang diharapkan. Seesi ino bertujuan memfasilitasi partisipan mampu membuat strategi berdasarkan hasil analisis SWOT.

Kedua sesi tersebut mengarah kepada kategori kesulitan utama pertama dan ketiga dari taxonomy of career decision-making difficulties yaitu keterlibatan untuk membuat keputusan karier dengan segera (lack of readiness) dan ketidakkonsistenan dua jenis informasi (inconsisten information). Lack of readiness adalah kurangnya orientasi individu terhadap masa depan serta kecenderungan untuk kurang terlibat dalam persiapan untuk membuat keputusan dengan segera yang terkait dengan karier (Gati \& Levin, 2014). Melalui evaluasi terhadap pilihan karier dan pembuatan rencana karier maka siswa digugah secara sadar untuk siap dalam melakukan perencanaan karier. Ketika siswa mengalami ketidakpastian atau keraguan maka fungsi fasilitator adalah melakukan identifikasi terhadap kesulitan tersebut sehingga siswa tergugah untuk membuat solusi terhadap kesulitan tersebut. Berdasarkan hasil analisa terbukti bahwa tingkat kesulitan kategori spesifik yaitu kurangnya motivasi untuk membuat keputusan, adanya keraguan yang terjadi 
dalam membuat suatu keputusan, dan disfungsi keyakinan atau pemikiran mengenai karier cenderung menurun secara signifikan.

Data juga menunjukkan bahwa CDMC tidak secara signifikan dapat menurunkan masalah kesulitan keputusan karier karena informasi yang tidak konsisten (inconsistent information). Siswa akan lebih mudah untuk mengambil keputusan karier ketika informasi yang dimiliki kongruen. Siswa akan berusaha untuk mencari informasi yang sesuai dengan kebutuhannya. Namun sering kali terjadi miskonsepsi antara anak, orang tua, dan guru (Mbetse, 2002). Terkadang inkonsistensi informasi dapat menimbulkan konflik internal ataupun eksternal. Pada modul CDMC informasi karier cenderung konsisten sehingga siswa kurang memiliki pengalaman untuk menangani permasalahan dengan informasi yang tidak konsisten. Dengan demikian, modul dalam penelitian ini perlu penyempurnaan untuk menangani permasalahan tersebut. Gati dan Levin (2014) menjelaskan bahwa konselor memiliki keahlian yang dapat menyelesaikan masalah klien yang berkaitan dengan emosi dan pemrosesan informasi. Dengan demikian, pelibatan konselor dan bukan hanya fasilitator dapat menjadi salah satu alternatif dalam kekurangan modul CDMC tersebut.

\section{Kesimpulan}

Menutupi kesenjangan yang ada, penelitian ini menguji efektivitas career decision-making course (CDMC) khususnya pada siswa sekolah menengah atas dalam mengurangi kesulitan dalam penentuan karier. Pelatihan tersebut terbukti efektif mengurangi kesulitan tersebut, yang berimplikasi pada pentingnya siswa dibekali dengan informasi yang memadai terkait dengan apa yang bisa mereka lakukan setelah menyelesaikan pendidikan. Meskipun demikian, masih terdapat beberapa kekurangan dalam penelitian ini. Pertama adalah bahwa proses evaluasi masih sebatas pada level 2 dari Kirkpatrick (1998) yaitu proses belajar. Pendalaman pada level 3 yang berkaitan dengan perilaku bekerja sama dengan guru bimbingan konseling perlu didalami, untuk melihat pengambilan keputusan siswa dalam memilih jurusan di perguruan tinggi. Kelemahan kedua adalah uji coba modul hanya pada satu sampel yaitu sekolah menengah swasta. Kelemahan ini bisa diatasi dnegan uji coba pada sekolah dengan perbedaan karakteristik, misalnya pada sekolah negeri dan sekolah internasional. Langkah lanjutan ini perlu dilakukan karena perbedaan karakteristik akan menghasilkan perbedaan kesulitan keputusan karier (Gati \& Saka, 2001), yang pada akhirnya sangat bermanfaat untuk menguji generalisasi dari modul yang dikembangkan.

\section{Daftar Pustaka}

Aminuddin, D., \& Mulyadi, M. (2020). Efektivitas layanan informasi karier dalam meningkatkan kemampuan perencaanaan karier siswa. Consilium: Berkala Kajian Konseling dan Ilmu Keagamaan, 6(2), 52-62. https://doi.org/10.37064/consilium.v6 i2. 6365

Atmaja, T. T. (2014). Upaya meningkatkan perencanaan karier siswa melalui bimbingan karier dengan penggunaan media modul. Psikopedagogia Jurnal Bimbingan dan Konseling, 3(2), 57-66. https://doi.org/10.12928/psikopedago 
gia.v3i2.4466

Christensen, L. B. (2010). Experimental methodology $\left(10^{\text {th }}\right.$ ed.). Allyn \& Bacon.

Cohen, J. (1988). Statistical power analysis for the behavioural sciences. Erlbaum.

Cornell, R. M., Johnson, C. B., \& Schwartz Jr, W. C. (2013). Enhancing student experiential learning with structured interviews. Journal of Education for Business, 88(3), 136146.

https://doi.org/10.1080/08832323.201 2.659296

Creed, P., Patton, W., \& Prideaux, L.-A. (2006). Causal relationship between career indecision and career decisionmaking self-efficacy: A longitudinal cross-lagged analysis. Journal of Career Development, 33(1), 47-65. https://doi.org/10.1177/08948453062 89535

Crites, J. O. (1978). Career maturity inventory: Administration \& use manual ( $2^{\text {nd }}$ ed.). CTB/McGraw-Hill. http://www.vocopher.com/CMI-

A2/CMI_Manual.pdf

Dewanti, A. L. (2018). Perancangan modul career decision-making course untuk mengurangi kesulitan dalam membuat keputusan karier pada mahasiswa Fakultas Psikologi Universitas Padjadjaran [Master Tesis, Universitas Padjadjaran]. https://pustaka.unpad.ac.id/archives/1 66200

Fadhillah, S. H., \& Yudiana, W. (2020). Kesulitan pengambilan keputusan karier pada siswa di daerah rural: Bagaimana peran dukungan sosial? Persona:Jurnal Psikologi Indonesia, 9(2), 229-248. https://doi.org/10.30996/persona.v9i2
.3375

Fouad, N., Cotter, E. W., \& Kantamneni, N. (2009). The effectiveness of a career decision-making course. Journal of Career Assessment, 17(3), 338-347.

https://doi.org/10.1177/10690727083 30678

Gati, I., Krausz, M., \& Osipow, S. H. (1996). A taxonomy of difficulties in career decision making. Journal of Counseling Psychology, 43(4), 510. https://doi.org/10.1037/00220167.43.4.510

Gati, I., \& Levin, N. (2014). Counseling for career decision-making difficulties: Measures and methods. Career Development Quarterly, 62(2), 98-113. https://doi.org/10.1002/j.21610045.2014.00073.x

Gati, I., \& Saka, N. (2001). High school students' career-related decisionmaking difficulties. Journal of Counseling and Development, 79(3), 331-340.

https://doi.org/10.1002/j.15566676.2001.tb01978.x

Hidayati, R. (2015). Layanan informasi karier membantu peserta didik dalam meningkatkan pemahaman karier. Jurnal Konseling GUSJIGANG, 1(1), 1-10.

https://doi.org/10.24176/jkg.v1i1.258

Jayanti, I. S. (2018). Adaptasi instrumen career decision-making difficulties questionnaire (CDDQ) pada mahasiswa di Indonesia [Master Tesis, Universitas Padjadjaran]. https://pustaka.unpad.ac.id/archives/1 69413

Kirkpatrick, D. (1998). The four levels of evaluation. In S. M. Brown \& C. J. Seidner (Eds.), Evaluating corporate 
training: Models and issues. Springer. https://doi.org/10.1007/97894-011-4850-4_5

Kolb, D. A. (1976). Management and the learning process. California Management Review, 18(3), 21-31. https://doi.org/10.2307/41164649

Kolb, D. A. (2014). Experiential learning: Experience as the source of learning and development. FT press.

Komara, I. B. (2016). Hubungan antara Kepercayaan diri dengan prestasi belajar dan perencanaan karier siswa SMP. Psikopedagogia Jurnal Bimbingan dan Konseling, 5(1), 3342.

https://doi.org/10.12928/psikopedago gia.v5i1.4474

Lam, M., \& Santos, A. (2018). The impact of a college career intervention program on career decision selfefficacy, career indecision, and decision-making difficulties. Journal of Career Assessment, 26(3), 425444.

https://doi.org/10.1177/10690727177 14539

Mbetse, D. J. (2002). The development of an intervention strategy for career education in Bushbuckridge [Master Thesis, University of Pretoria]. https://repository.up.ac.za/bitstream/h andle/2263/26703/dissertation.pdf

Nathan, R., \& Hill, L. (2005). Career counselling. Sage Publications.

Novitasari, P. (2013). Meningkatkan pemahaman cara membuat keputusan karier melalui layanan informasi karier. Indonesian Journal of Guidance and Counseling: Theory and Application, 2(1), 49-54. https://doi.org/10.15294/ijgc.v2i1.212 5

Nurihsan, A. J., \& Sudianto, A. (2005). Manajemen bimbingan dan konseling di SMP. Grasindo.

Pramudi, H. (2015). Kemampuan pengambilan keputusan karier siswa kelas XI di SMA Negeri 1 Kutasari Purbalingga. Jurnal Bimbingan dan Konseling, 2(4), 1-17. http://journal.student.uny.ac.id/ojs/ind ex.php/fipbk/article/view/171

Risqiyain, L. H., \& Purwanta, E. (2019). Pengembangan multimedia interaktif informasi karier untuk meningkatkan kematangan karier siswa sekolah menengah kejuruan. Jurnal Kajian Bimbingan dan Konseling, 4(3), 8893. https://doi.org/10.17977/um001v4i32 019 